\title{
NBP WOBEC KRYZYSU NA RYNKACH FINANSOWYCH
}

\section{WSTĘP}

Trudności występujące od jesieni 2008 roku na rynku kredytowym spowodowały konieczność podjęcia działań ze strony Narodowego Banku Polskiego. Jego zadaniem stało się odbudowanie zaufania wobec instytucji kredytowych, zapewnienie stabilności systemu finansowego w Polsce, a także utrzymanie wzrostu gospodarczego.

Choć globalny kryzys finansowy nie spowodował drastycznego załamania się funkcjonowania rynków finansowych w Polsce, to jednak wywołał szereg zjawisk niekorzystnych z ekonomicznego i społecznego punktu widzenia. Stąd podobnie jak banki centralne na całym świecie, NBP wziął na siebie ciężar amortyzowania wstrząsów na polskim rynku finansowym. Przybrało to postać standardowych i niestandardowych jego działań.

\section{OGÓLNA CHARAKTERYSTYKA SYTUACJI GOSPODARCZEJ NA ŚWIECIE I W POLSCE W LATACH 2007-2009}

Zapoczątkowany w 2007 roku w Stanach Zjednoczonych kryzys finansowy związany z kredytami subprime spowodował bardzo silne zawirowania $\mathrm{w}$ funkcjonowaniu rynków. Jego przejawami były zarówno upadki, przejęcia bądź utrata pozycji konkurencyjnej poważnej części instytucji finansowych, które były strategicznymi inwestorami banków w Polsce. W konsekwencji w 2008 roku zaburzenia na rynku amerykańskim przekształciły kryzys finansowy w globalny kryzys gospodarczy. Reakcją na te wydarzenia było szybkie obniżanie stóp procentowych w USA, Wielkiej Brytanii, Szwajcarii i UE (nawet do zera przez banki centralne), jak również uruchomienie przez niektóre z nich tzw. ,niestandardowych działań". 
W tak ukształtowanej sytuacji - niejako swoistym efektem drugiej rundy - była oczywista perspektywa pogorszenia sytuacji finansów publicznych i ostateczne wystąpienie silnego wzrostu deficytów budżetowych w krajach UE. Konsekwencje tych negatywnych zjawisk na rynkach światowych nie dały na siebie długo czekać i na zasadzie efektu domina spowodowały poważne pogorszenie sytuacji w krajach Europy Środkowo-Wschodniej, rzutujące na osłabienie walut lokalnych, w tym także w Polsce. Wskutek pogłębienia się kryzysu na rynkach światowych nastąpiła również wyprzedaż aktywów krajów z grupy emerging markets, w tym także walut, gwałtownie spadły ceny surowców i załamaniu uległy procesy inwestycyjne.

W 2009 roku pogłębieniu uległy negatywne zjawiska, zaobserwowane w minionym roku. Odnotowano bardzo silny spadek koniunktury gospodarczej w krajach UE, w tym także - silnego partnera Polski w wymianie zagranicznej, jakim są Niemcy. Uzewnętrznił się wzrost deficytów budżetowych bardzo wielu gospodarek. Jednocześnie nastąpił wzrost bezrobocia, który w opiniach analityków - będzie nadal postępował. Pogorszenie sytuacji gospodarczej wysoko rozwiniętych gospodarek spowodowało ograniczenie inwestycji zagranicznych i przepływu kapitałów na rynki rozwijające się. Ponadto towarzyszyło im obniżenie ocen ratingowych dla tzw. emerging markets.

W analizowanym okresie sytuacja polskiej gospodarki była zróżnicowana. Rok 2007 i trzy kwartały 2008 roku charakteryzowały się szybkim tempem wzrostu gospodarczego. W tym względzie gospodarka polska korzystnie wyróżniała się wśród innych krajów Unii Europejskiej. Również w tym czasie nastąpił w Polsce spadek bezrobocia, któremu towarzyszył też wzrost płac, wynikający z dużego popytu rynkowego na czynnik ludzki, którego podaż znacznie się w ostatnich latach zmniejszyła ze względu na wyjazdy zagraniczne i podjęcie pracy przez Polaków w różnych państwach Europy.

W czwartym kwartale 2008 roku wystąpiło gwałtowne osłabienie złotego. Ponadto ujawnily się negatywne zjawiska w postaci silnego pogorszenia wyników finansowych przedsiębiorstw, gwałtownego spadku nastrojów podmiotów gospodarujących, a także załamaniu uległa sytuacja na polskim rynku giełdowym, powodująca poważną bessę na rynku akcji i konieczność zastopowania planów prywatyzacji GPW w Warszawie. Pod koniec tegoż roku bardzo niekorzystnie kształtowała się sytuacja w zakresie deficytu budżetowego, który uległ dalszemu pogłębieniu - do 2,7\% PKB (2,0\% w 2007 r.), choć w porównaniu do innych krajów - uzyskany rezultat należał do relatywnie dobrych ${ }^{1}$.

$\mathrm{Na}$ tle wyżej wskazanych negatywnych symptomów gospodarczych - jedynie w odniesieniu do inflacji odnotowano spadek presji inflacyjnej i zmniejszenie inflacji z 4\% do 3,3\% (grudzień 2007/grudzień 2008). Złożyły się na to zarów-

\footnotetext{
${ }^{1}$ Raport o sytuacji banków w 2008 roku, Urząd KNF, Warszawa 2009, s. 12.
} 
no silny spadek cen surowców energetycznych i rolno-spożywczych na rynkach światowych w 2008 roku, jak i osłabienie tempa wzrostu wynagrodzeń pod koniec tegoż roku.

Pomimo relatywnie pomyślnego przystosowania gospodarki polskiej do obecnego kryzysu dalsze jej perspektywy są uzależnione od czasu utrzymywania się recesji na rynkach światowych. Obserwacja zjawisk w ostatnich miesiącach 2009 roku wskazuje na osłabienie napięć kryzysowych i perspektywy odbudowy wzrostowego trendu globalnej gospodarki. Nadal jednak dają o sobie znać różne negatywne sygnały, które mogą opóźnić proces dźwigania się z recesji gospodarki światowej. Do najczęściej wskazywanych należą niejasna sytuacja kształtowania się wyników finansowych banków, powiększanie się deficytów budżetowych i bezrobocia. Silne są obawy co do nadejścia nowej fali kryzysu w 2010 roku w gospodarce niemieckiej.

\section{SYTUACJA BANKÓW W POLSCE W LATACH 2007-2009}

Podobnie jak we wcześniejszych rozważaniach - charakteryzując działalność banków w analizowanych latach - można wyróżnić dwa okresy. Rok 2007 i trzy początkowe kwartały 2008 roku wyróżniały się pomyślnymi warunkami wzrostu gospodarczego, a także wysokim współczynnikiem optymizmu podmiotów gospodarujących. Z kolei IV kwartał 2008 i pierwsze półrocze 2009 roku przyniosły zdecydowane pogorszenie rezultatów finansowych banków.

W pierwszym okresie wśród korzystnych zjawisk należałoby wskazać na rozwój sektora bankowego, przejawiający się we wzroście aktywów, przyroście depozytów ludności, podwyższenie kapitałów banków (wynikające z przeznaczenia zysku z 2007 r. na ich wzrost). Ponadto okres ten charakteryzował się bardzo poważnym zwiększeniem sumy bilansowej sektora bankowego, która przekroczyła po raz pierwszy bilion złotych, a także dynamicznym rozwojem akcji kredytowej.

Począwszy od IV kwartału, osłabieniu uległa aktywność rynku międzybankowego przy równoczesnym wzroście kosztu pozyskiwania pieniądza na rynku. Akcja kredytowa $\mathrm{z}$ końcem 2008 roku została zahamowana w poważnym stopniu. Wspomniane tendencje doprowadziły do walki konkurencyjnej o depozyty klientów, określanej jako tzw. wojna depozytowa. Ponadto sektor bankowy w znacznym stopniu zwiększył swoje inwestycje w papiery skarbowe i bony pieniężne NBP (ze względu na chęć zwiększenia rezerw płynności). Zarejestrowano ponadto pogłębienie się luki między depozytami i kredytami. Nastąpił istotny wzrost należności zagrożonych i „pod obserwacją”, głównie od gospodarstw domowych, powodujący wzrost niezbędnych rezerw/odpisów za niespłacone i opóźniające się regulowanie kredytów. Powyższe kwestie ilustruje tabela 1. 
Tabela 1. Należności zagrożone sektora finansowego

\begin{tabular}{|c|c|c|c|c|c|}
\hline \multirow{2}{*}{ SEKTOR } & \multirow{2}{*}{ OKRES } & \multirow{2}{*}{$\begin{array}{l}\text { UDZIAŁ NALEŻNOŚCI } \\
\text { ZAGROŻONYCH } \\
\text { W NALEŻNOŚCIACH } \\
\text { OGÓŁEM }\end{array}$} & \multicolumn{2}{|c|}{$\begin{array}{l}\text { UDZZIAE NALEŻNOŚCI ZAGROŻONYCH } \\
\text { W NALEŻNOŚCIACH OGÓŁEM }\end{array}$} & \multirow{2}{*}{$\begin{array}{l}\text { WIELKOŚĆ REZERW/ } \\
\text { /ODPISÓW UTWORZO- } \\
\text { NYCH NA NALEŻNOŚCI } \\
\text { ZAGROŻONE } \\
\text { W MLN ZK }\end{array}$} \\
\hline & & & $\begin{array}{l}\text { GOSPODARSTW } \\
\text { DOMOWYCH }\end{array}$ & PRZEDSIĘBIORSTW & \\
\hline \multirow{6}{*}{ 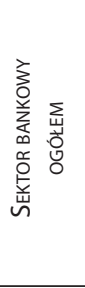 } & XII 2006 & 5,2 & 5,6 & 9,7 & 16594,8 \\
\hline & VI 2007 & 4,7 & 4,8 & 8,3 & 16366,4 \\
\hline & XII 2007 & 4,0 & 4,1 & 6,9 & 15621,1 \\
\hline & VI 2008 & 3,8 & 3,8 & 6,2 & 15936,9 \\
\hline & XII 2008 & 3,7 & 3,5 & 5,9 & 16427,4 \\
\hline & VI 2009 & 5,4 & 4,2 & 10,0 & 20665,7 \\
\hline \multirow{6}{*}{ 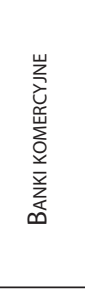 } & XII 2006 & 5,5 & 5,9 & 10,0 & 16032,6 \\
\hline & VI 2007 & 5,0 & 5,1 & 8,6 & 15793,1 \\
\hline & XII 2007 & 4,3 & 4,4 & 7,1 & 14982,8 \\
\hline & VI 2008 & 4,2 & 4,1 & 6,5 & 15175,9 \\
\hline & XII 2008 & 4,0 & 3,7 & 6,2 & 15464,0 \\
\hline & VI 2009 & 5,9 & 4,4 & 10,6 & 19394,2 \\
\hline \multirow{6}{*}{ 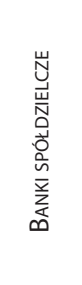 } & XII 2006 & 2,5 & 3,2 & 6,9 & 443,5 \\
\hline & VI 2007 & 2,2 & 2,7 & 5,7 & 451,5 \\
\hline & XII 2007 & 2,0 & 2,4 & 5,5 & 453,9 \\
\hline & VI 2008 & 1,9 & 2,2 & 5,1 & 450,9 \\
\hline & XII 2008 & 1,8 & 2,1 & 5,3 & 463,1 \\
\hline & VI 2009 & 2,0 & 2,2 & 5,8 & 473,0 \\
\hline
\end{tabular}

Źródło: aneksy statystyczne Raportów o sytuacji banków, Urząd KNF Warszawa, lata 2008-2009.

$\mathrm{Na}$ podstawie informacji zawartych w tabeli 1 można zauważyć wyraźną tendencję poprawy udziału należności zagrożonych w należnościach ogółem w okresie do IV kw. 2008 roku włącznie. Dotyczyła ona w jednakowym stopniu banków komercyjnych, jak i spółdzielczych. Jednak należy podkreślić, że udział należności zagrożonych w portfelach banków spółdzielczych był o 50-70\% niższy niż w bankach komercyjnych.

Pogorszenie jakości portfela banków, niezależnie od ich rodzaju, wystąpiło w 2009 roku. Z punktu widzenia rodzaju podmiotów wyższym udziałem należności zagrożonych charakteryzowały się przedsiębiorstwa. Był on mniej więcej 
o połowę większy niż w przypadku gospodarstw domowych. Prawidłowość ta pozostawała charakterystyczna niezależnie od typu kredytodawcy. Jeśli chodzi o ocenę wielkości rezerw/odpisów tworzonych na należności zagrożone, to należy stwierdzić, że po niewielkim ich spadku w II półroczu 2007 i I półroczu 2008 roku wzrosły one $\mathrm{o} 1 / 4$ (w wartościach nominalnych). Jedynie w bankach spółdzielczych sytuacja przedstawiała się nieco inaczej, gdyż rezerwy rosły w całym analizowanym okresie, lecz w dalece mniejszym stopniu niż w odniesieniu do banków komercyjnych (jedynie $40 \mathrm{mln} \mathrm{zl}$ ). Wśród innych istotnych charakterystyk tego okresu należy wskazać spadkowy trend cen na rynku nieruchomości oraz utrzymanie ratingu Polski na niezmienionym poziomie ${ }^{2}$.

W pierwszej połowie 2009 roku obserwowane pod koniec 2008 roku negatywne zjawiska uległy dalszemu pogłębieniu w polskiej gospodarce. Znalazły one wyraz w obniżeniu tempa wzrostu gospodarczego, wzroście bezrobocia oraz zmniejszeniu wpływów podatkowych dla budżetu, zmuszając do nowelizacji ustawy budżetowej. Negatywne konsekwencje przedłużającego się kryzysu finansowego na świecie spowodowały w rezultacie w Polsce gwałtowne załamanie wymiany zagranicznej (zarówno eksportu, jak i importu) oraz silne osłabienie relacji złotego w stosunku do innych walut. Nadal też utrzymywały się negatywne nastroje gospodarstw domowych i przedsiębiorstw. Pomimo wszystkich niekorzystnych uwarunkowań zewnętrznych i wewnętrznych, rzutujących na sytuację Polski w analizowanym okresie, jej stan na tle innych krajów UE rysował się zdecydowanie lepiej. Większą odporność na kryzys w porównaniu do innych państw europejskich polska gospodarka zawdzięcza jej mniejszej otwartości, relatywnie dużemu rynkowi wewnętrznemu, dużemu stopniowi zróżnicowania działalności wytwórczej i usługowej, wysokiej elastyczności przedsiębiorstw. Ponadto płynny kurs walutowy umożliwił łatwiejszą adaptację do szoków zewnętrznych ${ }^{3}$. Również niski poziom ubankowienia w Polsce oraz nieporównywalnie słabsza ekspozycja na tzw. „toksyczne” aktywa - sprzyjały łagodniejszemu odczuwaniu skutków kryzysu. Akcja kredytowa nie uległa gwałtownemu załamaniu, tylko ograniczeniu. W stosunku do spadku dochodów budżetowych podjęto stosowne działania, polegające na ograniczeniu wydatków oraz na zmianie sposobu finansowania części zadań budżetowych.

Banki stały się wierzycielem netto sektora niefinansowego $\mathrm{z}$ uwagi na niedostatek depozytów i brak możliwości uzyskania zasilenia na rynku międzynarodowym - perspektywa rozwijania bądź utrzymania akcji kredytowej stała się wątpliwa, bardziej kosztowna i trudna. Ze względu na nadwyżkę dotąd udzielo-

\footnotetext{
${ }^{2}$ Ibidem, s. 13.

${ }^{3}$ Informacja o sytuacji banków po pierwszym pótroczu 2009 r., Urząd KNF, Warszawa 2009, s. 9.
} 
nych kredytów nad depozytami (por. tabela 2) poważnym wyzwaniem w sytuacji kryzysu będą możliwości pozyskania środków na działalność kredytową banków.

Analiza relacji kredytów i depozytów wskazuje wyraźnie na zmniejszanie się w coraz większym stopniu bazy depozytowej od końca 2007 roku. Szczególnie wyraźne jest to zjawisko w stosunku do banków komercyjnych, a wśród rodzajów podmiotów gospodarczych - w bardzo silnym stopniu dotyczy przedsiębiorstw. „Wojna depozytowa” w 2008 roku, mająca na celu przejęcie likwidowanych jednostek uczestnictwa w funduszach inwestycyjnych, nie była w stanie zrównoważyć przyjętymi lokatami wielkości kwoty udzielonych kredytów przez banki komercyjne.

Natomiast całkowicie odmiennie kształtowała się relacja kredytów do depozytów w przypadku banków spółdzielczych. Kryzys finansowy nie odegrał istotniejszej roli w załamaniu bazy depozytowej. Przeważała ona nad kredytami banków spółdzielczych w połowie 2009 roku w wysokości około $12 \mathrm{mld}$ zł, co może stanowić perspektywę dla poprawy sytuacji na rynku finansowym w kolejnych miesiącach i przyszłym roku.

Tempo przyrostu wartości kredytów w 2008 roku było najwyższe w całym okresie transformacji ${ }^{4}$. Szczególnie wysoka była dynamika kredytów gospodarstw domowych - o 45\% (głównie z powodu boomu na rynkach kredytów hipotecznych, a także wskutek silnego obniżenia kursu złotego). Udział kredytów ludności w portfelu kredytowym wzrósł do 62,1\% w 2008 roku. Wcześniej, do 2005 roku, dominowały kredyty dla przedsiębiorstw.

Silnie i niebezpiecznie wzrosło zadłużenie gospodarstw domowych w walutach obcych na długie okresy. Kredyty walutowe stanowiły 40,6\% wartości portfela kredytów gospodarstw domowych (25,2\% wszystkich kredytów). Istniejąca w 2008 roku sytuacja na rynkach kredytów przyczyniła się do wzrostu ryzyka systemowego, co mogło doprowadzić do deprecjacji waluty krajowej. Ponadto, niektóre banki charakteryzowało znaczne zaangażowanie $\mathrm{z}$ tytułu opcji walutowych.

Niewątpliwie pogorszenie sytuacji na rynku kredytowym w Polsce miało także swoje źródła w zbyt liberalnej polityce kredytów mieszkaniowych. Strategia łagodzenia wymagań ocen zdolności kredytowej bardzo szybko zaczęła przynosić niekorzystne efekty. Zaostrzenie polityki kredytowej nastąpiło w IV kwartale 2008 roku. Przybrało ono postać:

- zwiększonych marż kredytowych,

- wprowadzenia lub zwiększenia wymaganego poziomu wkładu własnego,

- zwiększenia wymagań w zakresie zabezpieczeń,

- skrócenie okresu kredytowania,

- ograniczania kredytów walutowych.

\footnotetext{
${ }^{4}$ Raport..., s. 41.
} 
Podobne tendencje boomu kredytowego w 2008 roku i wyraźne zahamowanie kredytowania w IV kw. tego roku odnotowano również w przypadku przedsiębiorstw. Ujawnił się wówczas rosnący deficyt banków w rozliczeniach z sektorem finansowym. Ponadto ograniczeniu uległy depozyty przedsiębiorstw.

Spowolnienie akcji kredytowej w 2008 roku zarówno dla gospodarstw domowych, jak i przedsiębiorstw ilustrują wykresy 1-2. Konsekwencją splotu wszystkich niżej wspomnianych przesłanek był spadek wyników finansowych sektora bankowego w IV kwartale 2008 roku.

Tabela 2. Kredyty i depozyty sektora finansowego* w mld zł

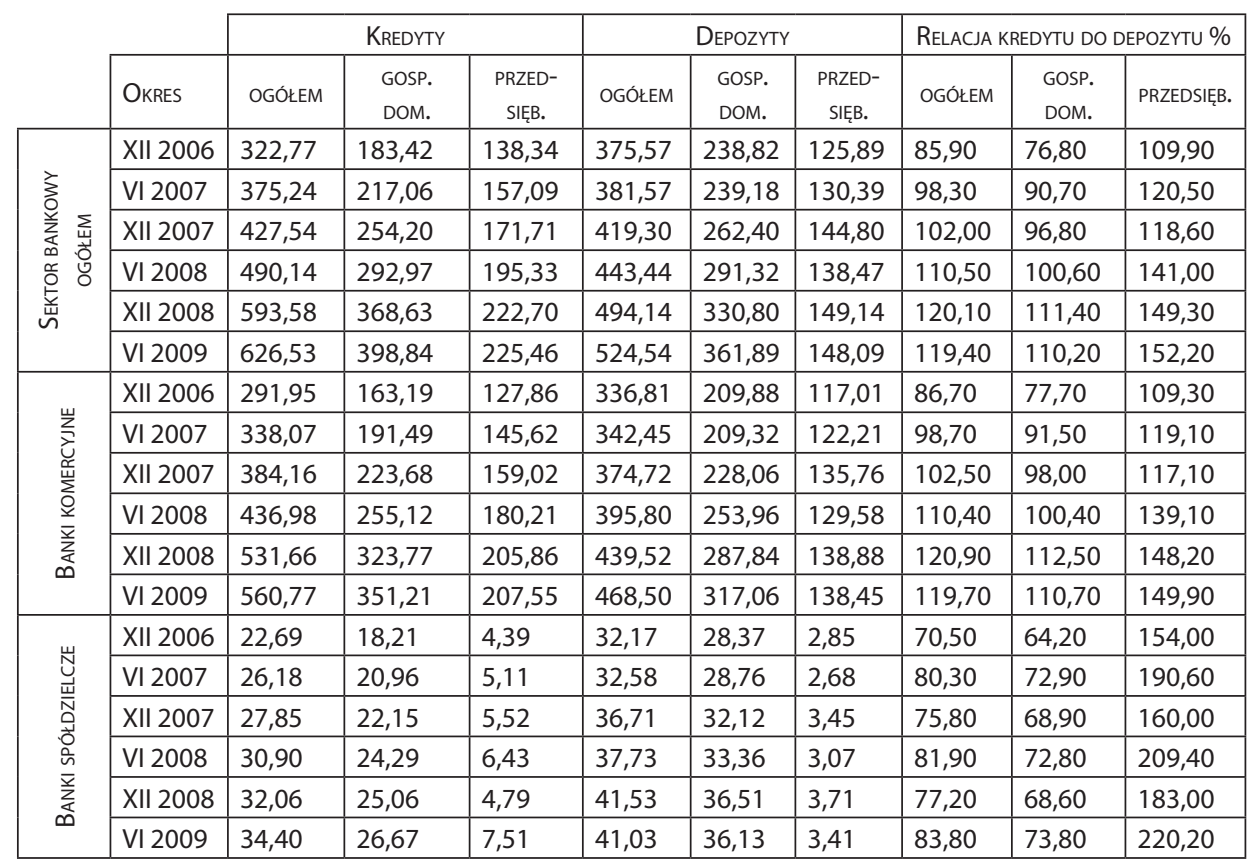

Źródło: aneksy statystyczne Raportów o sytuacji banków, Urząd KNF Warszawa, lata 2008-2009, oraz opracowanie własne.

Ocena działalności sektora bankowego w 2009 roku jest niejednoznaczna. Pomimo niewątpliwej poprawy jego sytuacji, mającej wyraz w amortyzowaniu wcześniejszych negatywnych zjawisk, nadal utrzymywały się pewne niepokojące sygnały. Wśród korzystnych tendencji można wskazać zachowanie przez sektor bankowy w Polsce stabilnej sytuacji w zakresie płynności, potężny wzrost kapitałów (i współczynnika wypłacalności) oraz silny wzrost depozytów gospodarstw

*Wartości nominalne 
domowych, wynikający z zamiany lokat w funduszach inwestycyjnych na lokaty bankowe. Jednocześnie nastąpiło pozytywne odwrócenie struktury walutowej nowych kredytów mieszkaniowych na rzecz wzrostu kredytów złotowych oraz ustępowanie problemu opcji walutowych w transakcjach pochodnych z przedsiębiorstwami. Niepokój natomiast budzi pogorszenie się jakości portfela kredytowego oraz kontynuowanie liberalizacji standardów oceny zdolności w przypadku kredytów mieszkaniowych (przekroczenie maksymalnej wartości LtV). O 50\% obniżyły się wyniki finansowe banków. Towarzyszyły im spadek depozytów i obniżenie ratingu części banków komercyjnych. Od końca 2008 do końca czerwca 2009 roku należności zagrożone wzrosły o 27,3\%, a należności „pod obserwacją” - o $32,4 \%$.

Gospodarstwa domowe

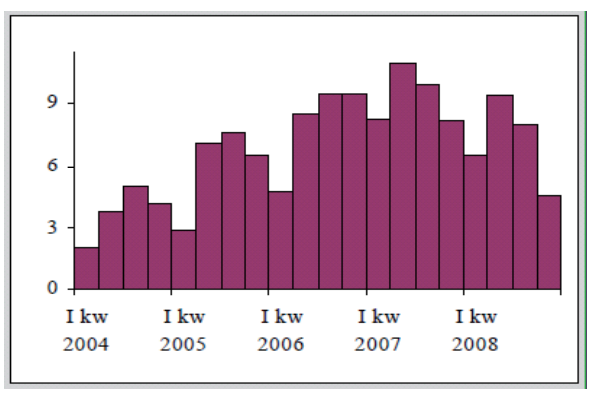

Przedsiębiorstwa

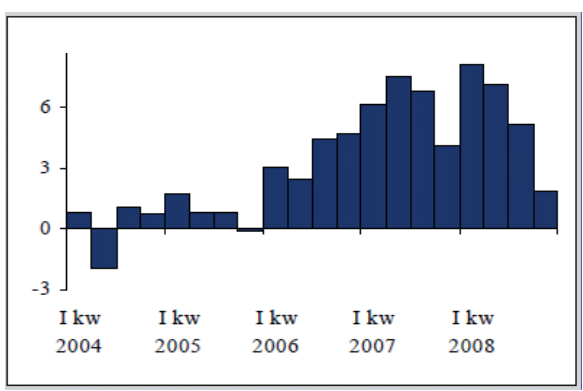

Wykres 1. Kwartalne tempo wzrostu kredytów skorygowane o zmianę kursów walut (\%) Źródło: Raport..., s. 51.

Gospodarstwa domowe

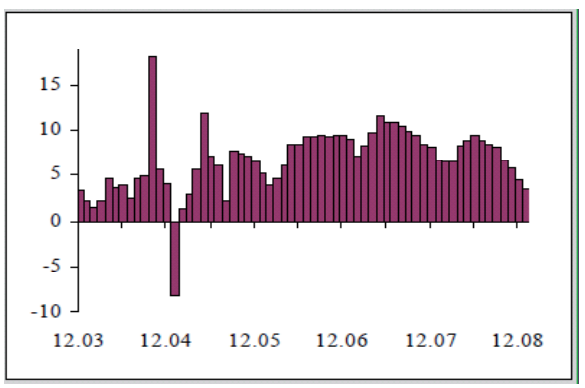

Przedsiębiorstwa

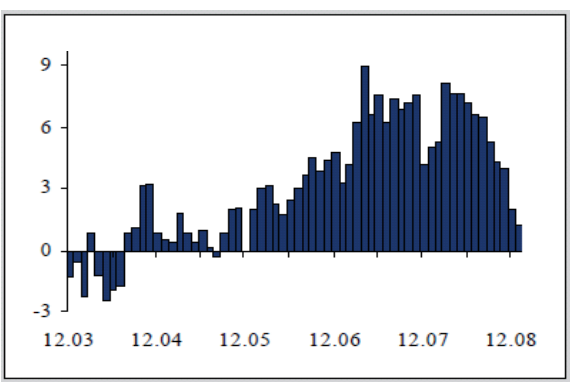

Wykres 2. Kroczące kwartalne tempo wzrostu kredytów skorygowane o zmianę kursów walut (\%)

Źródło: Raport..., s. 52. 
W obliczu niekorzystnej sytuacji makroekonomicznej, związanej ze spowolnieniem gospodarczym, banki musiały dostosować swoje działania biznesowe. Przejawiło się to przede wszystkim w formie zaostrzenia polityki kredytowej, wzroście portfela papierów skarbowych i bonów pieniężnych, silnej konkurencji na rynku depozytowym oraz ostrej kontroli kosztów. Cięcia kosztów przybrały głownie postać ograniczenia zatrudnienia i zahamowania tempa tworzenia nowych placówek.

W 2009 roku banki podjęły zdecydowane kroki w celu odwrócenia struktury walutowej kredytów (przede wszystkim mieszkaniowych) i przekształcenia ich w kredyty złotowe. Natomiast kredytobiorcom starającym się o kredyty walutowe postawiono zaostrzone wymagania w zakresie wysokości marż (tzw. marże „zaporowe”), dotyczące wysokości dochodów klientów bądź wycofania z oferty kredytów walutowych.

Istotną rolę odegrały działania nadzoru wymuszające na bankach rezygnację z kredytów zawartych w ofercie, na które nie posiadały źródeł finansowania. Z wyżej wymienionych względów zaostrzenie polityki kredytowej należy postrzegać jako korzystne w perspektywie długoterminowej stabilności sektora bankowego.

Zaostrzenie polityki kredytowej banków polegało ponadto na zwiększaniu pozaodsetkowych kosztów kredytu, zwiększeniu wymagań w zakresie zabezpieczeń, ograniczeniu stosowania uproszczonych procedur badania zdolności kredytowej. Pomimo powyższych działań wartość kredytów konsumpcyjnych rosła w 2009 r. (choć 3-krotnie wolniej niż w roku poprzednim). Obniżyła się także dynamika kredytów mieszkaniowych.

Zmiany sytuacji gospodarczej końca 2008 i 2009 roku wywołały znacznie silniejsze skutki dla działalności przedsiębiorstw, mające wyraz w zaostrzeniu polityki kredytowej banków wobec nich. Spowodowało to spadek popytu przedsiębiorstw na kredyty i rzeczywistą ich stagnację. Wobec firm zastosowano także wzrost marż i wymagań dotyczących zabezpieczeń oraz obniżono pułapy kredytowe. W najsilniejszym stopniu uderzyło to w potrzeby kredytowe sektora małych i średnich przedsiębiorstw ${ }^{5}$.

Do pozytywnych tendencji na rzecz zwiększenia bezpieczeństwa sektora bankowego wpłynęły decyzje WZA o pozostawieniu zysków wypracowanych w bankach w 2008 roku i niewypłacaniu dywidendy, co spowodowało wzrost ich kapitałów (funduszy) o $21,3 \%$.

\footnotetext{
${ }^{5}$ Informacja..., s. 19; Sytuacja na rynku kredytowym III kw. 2009 r., NBP, Warszawa 2009.

${ }^{6}$ Ibidem, s. 22.
} 


\section{ZMIANY W POSTĘPOWANIU BANKÓW CENTRALNYCH W WARUNKACH KRYZYSU FINANSOWEGO}

Aktualny kryzys na rynkach finansowych spowodował konieczność rewizji polityki pieniężnej prowadzonej przez banki centralne zarówno w USA, Europie, jak i w gospodarkach wschodzących, takich jak Polska. Przewartościowanie dotychczasowych działań banków centralnych dotyczy z jednej strony zadań przez nie podejmowanych, jak i stosowanych instrumentów. Zarówno doświadczenia FED-u, EBC, jak i banku Japonii dowodzą, że stopy procentowe przestały spełniać swoją funkcję, ponieważ nie oddziałują na gospodarkę i kurs walutowy z racji ich spadku prawie do zera lub ze względu na rozerwanie związku między rynkowymi stopami procentowymi a stopą referencyjną banku centralnego ${ }^{7}$.

Globalny kryzys finansowy przybrał postać tzw. credit crunch, czyli zjawiska znajdującego wyraz w coraz poważniejszych ograniczeniach dostępu do kredytu i zaostrzeniu warunków udzielania kredytów. Nastąpiło gwałtowne ograniczenie transakcji na rynku międzybankowym ze względu na wzrost obaw o regulowanie zobowiązań pomiędzy partnerami. Równocześnie duża presja popytu na tym rynku spowodowała wzrost kosztów pozyskiwania finansowania zewnętrznego. Efektem tych zdarzeń było zaniechanie transakcji na dłuższe terminy.

Konsekwencją braku skuteczności polityki stóp procentowych w obliczu kryzysu stało się odchodzenie ku niestandardowym rozwiązaniom w bankach centralnych. Zarówno utrzymanie stóp procentowych na niskim poziomie, jak i ich obniżanie stało się nieskuteczne (szczególnie gdy stopy te były bliskie zeru). Stąd w najważniejszych bankach centralnych na świecie pojawiły się działania polegające na ilościowym zwiększeniu pieniądza rezerwowego ${ }^{8}$.

Niestandardowe rozwiązania, jakie są przez nie wprowadzane, to tzw. quantitative easing ${ }^{9}$, polegające na zwiększeniu płynności sektora bankowego poprzez zakup aktywów finansowych. Tego rodzaju działanie banku centralnego zwiększa bazę monetarną (M0) i udział płynnych aktywów w systemie finansowym.

Bezpośrednie działania banków centralnych mają za zadanie „odtwarzać” rynki, które przestały istnieć, a takimi rynkami są rynek kredytów, rynek krótkoterminowych papierów bądź rynek międzybankowy. W związku z tym zmienia się układ partnerów tych rynków; partnerem banku na rynku międzybankowym staje się bank centralny. Będzie to implikowało nową sytuację obu uczestników ryn-

7 Wprowadzenie, [w:] Dziatania antykryzysowe banków centralnych, „Zeszyty BRE Bank-CASE” 2009, nr 101, s. 5-8.

${ }^{8}$ Por. działania FED-u. Patrz J. Pruski, Dziatalnośc antykryzysowa banków centralnych w dobie globalnego kryzysu finansowego, [w:] Dziatania..., s. 12, 17.

${ }_{9}$ Raport o stabilności systemu finansowego - czerwiec 2009, NBP, Warszawa czerwiec 2009, s. 21-22, używa się też synonimu credit easing. 
ku. Banki komercyjne przetransmitują część uzyskanej płynności z powrotem do banku centralnego, co będzie się łączyło z efektywnością ekonomiczną banków. W grę będzie wchodził koszt utrzymania nadwyżek w banku centralnym.

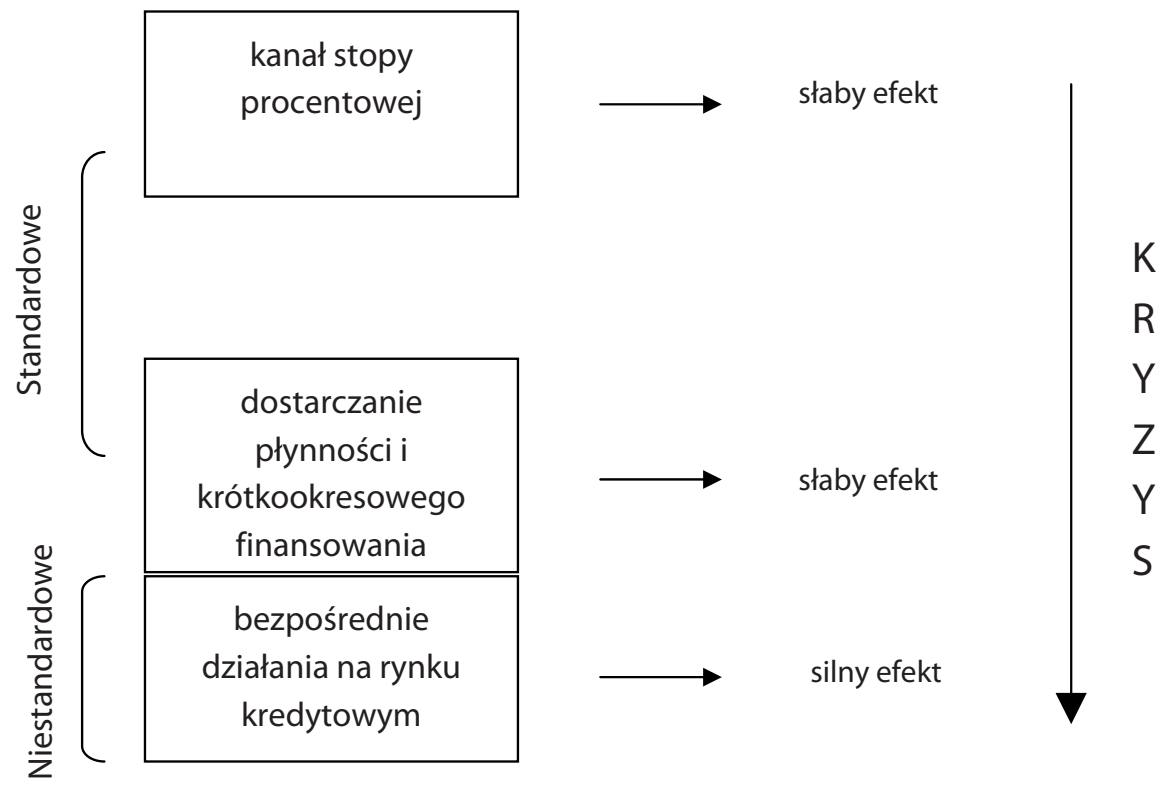

Wykres 3. Ewolucja działań banków centralnych pod wpływem kryzysu

Źródło: J. Pruski, Działalność antykryzysowa banków centralnych w dobie globalnego kryzysu finansowego, [w:] Działania..., „Zeszyty BRE Bank-CASE” 2009, nr 101.

Kolejnym działaniem ze strony banków centralnych jest współdziałanie z rządem w zakresie skupowania aktywów i pomocy w finansowaniu podmiotów prywatnych, kupujących tzw. toksyczne aktywa. Ma to ogromne znaczenie dla stabilizacji sektora finansowego. Tworzone są też specjalne linie swapowe $\mathrm{z}$ innymi bankami centralnymi. Rozszerzany jest także program pożyczek obligacji skarbowych. W ramach tzw. credit easing proponowane są zakupy emitowanych instrumentów (np. commercial papers). Rozszerzany jest katalog papierów wartościowych służących zabezpieczeniu transakcji z bankiem centralnym.

\section{DZIAŁANIA NBP W DOBIE KRYZYSU}

Podjęte przez NBP kroki, mające zmienić sytuację na rynku finansowym spowodowaną kryzysem, od jesieni 2008 do czerwca 2009 roku nie poprawiły w wy- 
raźny i satysfakcjonujący sposób warunków gospodarowania - zarówno podmiotów sektora finansowego, jak i niefinansowego. Zaproponowany w październiku 2008 roku Pakiet Zaufania w zbyt małym stopniu odpowiadał potrzebom banków i nie był w stanie replikować rynku międzybankowego. Same rozwiązania tego pakietu, choć bez wątpienia korzystne, miały zbyt słaby zasięg i siłę oddziaływania, bądź też zostały zbyt późno zainicjowane ${ }^{10}$.

Instrumenty zaproponowane w Pakiecie Zaufania nie były w stanie zamortyzować zjawiska credit crunch w Polsce.

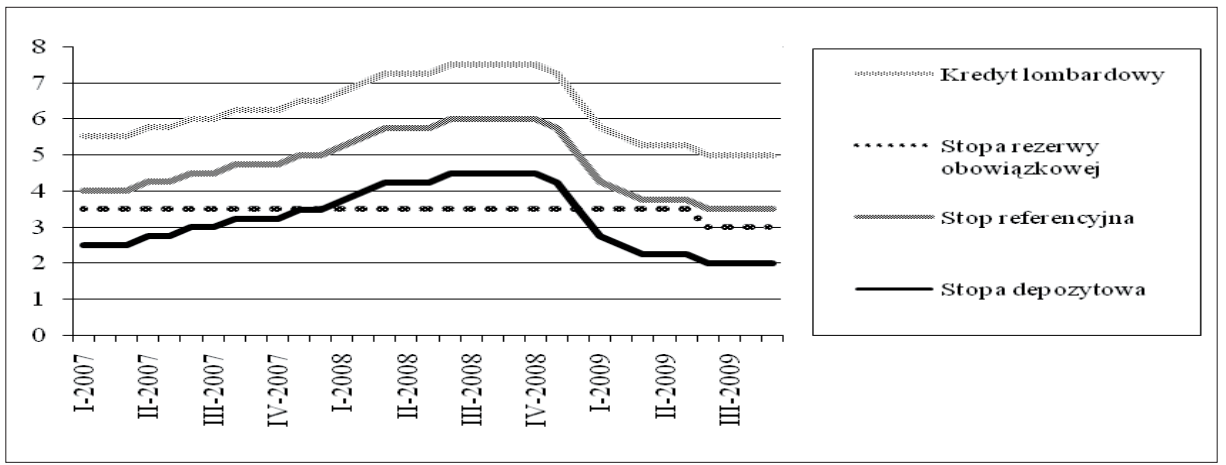

Wykres 4. Stopy procentowe Źródło: NBP.

Również obniżanie od jesieni 2008 do czerwca 2009 roku stóp procentowych nie odniosło oczekiwanych skutków. Spadek stopy referencyjnej o 225 pkt. bazowych w tym okresie nie spowodował odbudowy sytuacji na rynku kredytowym.

Zastosowane instrumenty miały niepodważalny aspekt psychologiczny, potwierdzający zaangażowanie banku centralnego w działania na rzecz stabilności systemu finansowego. Jednocześnie miały także charakter pragmatyczny, ponieważ prowadziły do poprawy i ustabilizowania rynków finansowych. Nie zlikwidowały braku zaufania na rynku i nie odbudowały aktywności rynku międzybankowego. Niewątpliwie udało się jednak rozpoznać oczekiwania sektora bankowego w stosunku do banku centralnego, dzięki przeprowadzonym na wiosnę spotkaniom z przedstawicielami banków komercyjnych i spółdzielczych, mającym na celu poprawę sytuacji na rynku kredytowym.

W kwietniu 2009 roku NBP zaproponował nową formułę współpracy sektora bankowego $\mathrm{z}$ bankiem centralnym na rzecz poprawy płynności rynku mię-

${ }_{10}$ M. Reluga, M. Gronicki, Podczas kryzysu liczy się szybkośc reakcji, „Rzeczpospolita” z dn. 7.01.2009, s. B9. 
dzybankowego, w postaci prac nad Pakietem na rzecz Rozwoju Akcji Kredytowej. $\mathrm{W}$ jego ramach NBP postanowił poszerzyć swoje zaangażowanie w proces zasilania sektora bankowego w kredyty. W Pakiecie na rzecz Rozwoju Akcji Kredytowej uwzględniono, sugerowane przez środowisko bankowe, dalsze działania wspomagające płynność sektora. Wprowadzono 6-miesięczne operacje repo, z możliwością nettingu. Wydłużeniu uległy operacje swapowe - realizowane w euro, dolarach i frankach szwajcarskich - z 1 tygodnia do 1 miesiąca. Rozszerzono także listę papierów wartościowych, służących zabezpieczeniu operacji otwartego rynku (OOR) - o papiery dłużne rejestrowane na KDPW, papiery skarbowe denominowane w euro - jak również uznano za dopuszczalne akceptowanie papierów z kuponem zapadającym w trakcie operacji.

Od maja do sierpnia 2009 roku NBP w dalszym ciągu uelastyczniał stosowanie instrumentów polityki pieniężnej. Obniżona została w praktyce od czerwca 2009 roku stopa rezerwy obowiązkowej z 3,5\% do 3\%, czego domagały się banki już wcześniej. Kontynuowano obniżkę stóp procentowych dzięki decyzjom RPP. Aktywizowano także transakcje swapowe poprzez publikowanie ich harmonogramów i zapowiedziano możliwości zwiększenia ich częstotliwości. Obniżanie stóp procentowych jest w sytuacji aktualnego kryzysu finansowego relatywnie nieskuteczne, na co wskazują doświadczenia innych banków centralnych na świecie, a także opinie polskich ekonomistów ${ }^{11}$. Mieszczą się one w kanonie standardowych pociągnięć władzy monetarnej.

Oprócz wyżej wspomnianych rozwiązań, wśród innych działań neutralizujących skutki kryzysu finansowego należy wymienić: wspieranie procesów plasowania obligacji skarbowych w walutach obcych na rynkach zagranicznych, organizowanie rynku pierwotnego dla banków i obligacji skarbowych oraz wtórnego dla bonów skarbowych, przejęcie przez NBP roli organizatora przetargów emisji obligacji BGK, gwarantowanych przez Skarb Państwa, czy rozszerzenie listy banków uprawnionych do pełnienia funkcji Dealera Rynku Pieniężnego. W ramach pomocy udzielonej bankom w stabilizowaniu płynności NBP zasilił rynek kwotą 21,5 mld złotych ${ }^{12}$.

$\mathrm{Na}$ sierpniowym spotkaniu kierownictwa NBP z bankami spółdzielczymi wskazano na potencjał, jaki posiadają te banki, i możliwości zasilenia polskiej gospodarki kwotą 10-11 mld zł wolnych rezerw (16,2\% wolnych środków) ${ }^{13}$. Kwota ta mogłaby się przyczynić do wzrostu PKB o 0,25 do 0,40 pkt. proc. Wynika ona z nadwyżki depozytów nad kredytami (por. tab. 2). Banki spółdzielcze mogłyby stać się poważnymi kredytodawcami, pod warunkiem ich dokapitalizowania.

${ }^{11}$ Por. M. Morawiecki, Dziatalność antykryzysowa banków centralnych a reakcje banków komercyjnych, [w:] Dziatania..., s. 7, 27.

${ }^{12}$ S. Skrzypek, Walczymy samotnie liczymy na wsparcie, „Forbes” 2009, nr 9.

${ }^{13}$ Potrzebne wzmocnienie - nbpnews, dokument internetowy z dnia 13.08.2009 r. 
Mogłoby to być możliwe w przypadku zwiększenia kwoty wolnej od rezerw obowiązkowych i objęcia gwarancjami Skarbu Państwa obligacji emitowanych przez banki spółdzielcze. Te propozycje wymagają wszakże uwzględnienia zmian legislacyjnych.

$\mathrm{Na}$ Forum Ekonomicznym w Krynicy Prezes NBP S. Skrzypek poinformował o pracach nad kolejnymi nowymi instrumentami wspomagającymi procesy kredytowe. Są to: wydłużenie operacji repo do 12 miesięcy, wprowadzenie kredytu dyskontowego oraz zakup przez NBP w operacjach otwartego rynku obligacji emitowanych przez banki. Pierwszy z tych instrumentów dostarczyłby nowego źródła finansowania na dłuższy niż dotąd (6 miesięcy) okres, co ułatwiłoby zarządzanie płynnością. Instrument ten może być stosowany także przez banki spółdzielcze. Całkowicie nowym instrumentem jest kredyt dyskontowy. Byłby on wykorzystywany przy refinansowaniu nowych kredytów. NBP przyjmowałby do dyskonta weksle wystawione przez przedsiębiorstwa.

Wykorzystanie tego instrumentu będzie uwarunkowane podpisaniem stosownej umowy między danym bankiem a bankiem centralnym. Ponadto RPP będzie musiała określić nową stopę procentową, jaką będzie stopa dyskontowa ${ }^{14}$.

Trzecim nowym instrumentem, który mógłby wspomagać długookresowe refinansowanie inwestycji, jest zakup przez NBP obligacji emitowanych przez banki w operacjach otwartego rynku. Byłby on dostępny również dla banków spółdzielczych. Możliwość jego stosowania wymagałaby spełnienia pewnych warunków. W myśl ustawy o NBP zakup obligacji możliwy byłby na rynku wtórnym. Natomiast same obligacje powinny być zarejestrowane w KDPW SA oraz mieć gwarancję (np. Skarbu Państwa, banku zrzeszającego lub innego banku) bądź też posiadać odpowiedni rating. Ponadto ten instrument wymaga uznania go przez RPP.

Proponowane trzy nowe instrumenty w gestii NBP są uwarunkowane zmianami w ustawie o NBP, która dopuszczałaby je do palety narzędzi NBP, mających na celu podwyższenie kapitałów banków oraz powiększenie kwoty zwolnionej z utrzymywania rezerwy obowiązkowej.

Równocześnie Prezes NBP zapowiedział podjęcie prac nad projektem ustawodawczym, który pozwoliłby bankowi centralnemu powołać Fundusz Rozwoju Systemu Bankowego. Miałby się on zajmować emisją, kupnem i sprzedażą papierów wartościowych, obrotem wierzytelnościami i udzielaniem pożyczek ban$\mathrm{kom}^{15}$. Jak wynika $\mathrm{z}$ zapowiedzi - pierwsze 12 -miesięczne operacje repo będą

${ }^{14}$ Stało się to faktem na posiedzeniu RPP w dniach 29-30.09.2009 r., Polityka monetarna nbpnews, dokument internetowy z dnia 1.10.2009 r., oraz Zatożenia polityki pieniężnej na rok 2010.

15 Spotkanie NBP z przedstawicielami banków - nbpnews, dokument internetowy z dnia 15.09.2009 r. 
zawierane w listopadzie 2009 roku. Z kolei kredyt dyskontowy i zakup obligacji zostaną udostępnione $\mathrm{z}$ początkiem 2010 roku.

Wyrazem ocen działalności NBP w obliczu kryzysu na rynku finansowym było uhonorowanie banku centralnego nagrodą „Home \& Market” wśród „Instytucji centralnych mających wpływ na kondycję rynku finansowego". Czy sektor bankowy równie wysoko oceni kroki NBP w kontekście stabilizowania rynku finansowego, pokaże kształtowanie się sytuacji w 2010 roku na tym rynku? Czy nowe instrumenty okażą się skuteczne i czy banki będą z nich korzystać, można będzie stwierdzić po uzyskaniu określonych doświadczeń w ich stosowaniu. Niewiadome nadal pozostają warunki zewnętrzne i procesy normowania się kryzysu finansowego w skali globalnej oraz ich wpływ na pokonanie zaistniałych zagrożeń $\mathrm{w}$ polskim systemie bankowym.

\section{NBP TOWARDS CRISIS ON FINANCIAL MARKETS}

SUMMARY

The article synthetically presents the economic situation in Poland as well as in the whole world during the crisis from 2007 to 2009. It also describes the condition of the Polish banking sector and points to its main problems, which accompany the occurrence of the credit crunch. The paper shows changes in the Central Banks' actions during the actual crisis. Then it presents and evaluates actions taken up by NBP from the beginning of the crisis (October 2008) to today. 
